\title{
Analisis Kemampuan Pemecahan Masalah Matematis Ditinjau dari Gaya Belajar Siswa di Masa Pandemi COVID-19
}

\author{
Intan Nur Fauziyah Al-Hamzah ${ }^{1}$, Subhan Ajiz Awalludin ${ }^{2}$ \\ ${ }^{1,2}$ Program Studi Pendidikan Matematika, Fakultas Keguruan dan Ilmu Pendidikan, Universitas Muhammadiyah Prof. Dr. Hamka, \\ Jl. Tanah Merdeka No. 20, Rt. 11/ Rw. 2, Rambutan, Ciracas, Jakarta Timur, Indonesia \\ intanalhamzah7@gmail.com
}

\begin{abstract}
Mathematics is seen as very important in the educational process and requires a strong understanding to improve the quality of mathematics learning. Mathematical problem-solving ability is influenced by various factors, such as students' varied learning styles. Since the COVID-19 pandemic, students are required to do online learning in solving mathematical problems. Therefore, solving mathematical problems in student learning styles must be understood by educators in teaching and learning mathematics so that educators can know the student's learning styles. This study uses a descriptive qualitative approach. The subjects used are students of class VII Muhammadiyah Daarul Arqam Depok totaling 30 students, where later there will be 3 students who are selected according to their learning styles. Researchers collected research data in the form of questionnaires, tests, and interview guidelines. The results of this study can be concluded that the type of learning style is visual, able to understand problems, able to plan problems, able to solve problems, and able to re-examine. Type of auditory learning style, able to understand the problem, less able to plan problems, less able to solve problems, and less able to re-examine. Kinesthetic learning style type, able to understand problems, less able to plan problems, able to solve problems, and less able to re-examine.
\end{abstract}

Keywords: Analysis, Problem solving of mathematical, Learning style

\begin{abstract}
Abstrak
Mata pelajaran matematika dipandang sangat penting dalam proses pendidikan dan memerlukan pemahaman yang kuat untuk meningkatkan kualitas pembelajaran matematika. kemampuan pemecahan masalah matematika di pengaruhi oleh berbagai macam faktor, di antaranya seperti gaya belajar siswa yang bervariasi. Semenjak adanya pandemi COVID-19 siswa diharuskan melakukan pembelajaran secara online dalam memecahkan masalah matematis. Oleh sebab itu pemecahan masalah matematika pada gaya belajar siswa harus dipahami oleh pendidik dalam kegiatan belajar mengajar matematika agar pendidik dapat mengetahui gaya belajar siswa tersebut. Penelitian ini menggunakan metode pendekatan kualitatif bersifat deskriptif. Subjek yang digunakan adalah siswa kelas VII Muhammadiyah Daarul Arqam Depok berjumlah 30 siswa, dimana nantinya akan ada 3 siswa yang dipilih sesuai dengan gaya belajarnya. Peneliti mengumpulkan data penelitian berupa angket, tes dan pedoman wawancara. Hasil penelitian ini dapat disimpulkan bahwa tipe gaya belajar visual, mampu memahami masalah, mampu merencanakan masalah, mampu menyelesaikan masalah, dan mampu memeriksa kembali. Tipe gaya belajar auditorial, mampu memahami masalah, kurang mampu merencanakan masalah, kurang mampu menyelesaikan masalah, dan kurang mampu memeriksa kembali. Tipe gaya belajar kinestetik, mampu memahami masalah, kurang mampu merencanakan masalah, mampu menyelesaikan masalah, dan kurang mampu memeriksa kembali.
\end{abstract}

Kata kunci: Analisis, Kemampuan pemecahan masalah matematis, Gaya belajar

Copyright (c) 2021 Intan Nur Fauziyah Al-Hamzah, Subhan Ajiz Awalludin

$\triangle$ Corresponding author: Intan Nur Fauziyah Al-Hamzah

Email Address: intanalhamzah7@gmail.com (Jl. Tanah Merdeka No. 20, Jakarta Timur, Indonesia)

Received 07 July 2021, Accepted 13 July 2021, Published 02 August 2021

\section{PENDAHULUAN}

Pada akhir tahun 2019 seluruh dunia telah dilanda dengan adanya kasus COVID - 19 dan pada pertengahan tahun 2020 kasus COVID-19 sudah memasuki Indonesia. Untuk mencegah angka penderita yang akan semakin meningkat, maka upaya pemerintah yang telah dilakukan di antaranya membuat peraturan baru berupa kebijakan yaitu mengganti sistem pembelajaran sementara dengan pembelajaran offline (pembelajaran langsung) menjadi pembelajaran online dari mulai level paling rendah sampai dilevel paling tinggi. Semenjak adanya pandemi COVID-19, siswa diharuskan melakukan pembelajaran online 
dalam memecahkan masalah matematis (Supriani et al., 2020).

Berbagai sudut pandang dalam matematika perlu dipahami oleh para pendidik matematika disekolah agar pembelajaran matematika tidak hanya menjelaskan tentang konsep matematika tetapi pendidik lebih berperan sebagai fasilitator (Dassa, 2018). Maka dari itu, peneliti menyimpulkan mata pelajaran matematika dipandang sangat penting dalam proses pendidikan dan memerlukan pemahaman yang kuat untuk meningkatkan kualitas pembelajaran matematika.

Dari hasil PISA 2015 (Programme for International Student Assessment) dalam matematika, Negara Kesatuan Republik Indonesia menempati level ke 56 dari 65 negara yang mengikuti PISA (OECD 2017), sedangkan hasil TIMSS 2015 (The Third International Mathematics and Science Study) Negara Kesatuan Republik Indonesia menempati level ke 44 dari 49 negara yang mengikuti TIMSS dengan rata-rata nilai 397 (Mullis et al., 2015). Oleh sebab itu, hasil TIMSS menunjukkan bahwa kemampuan pemecahan masalah matematika di Indonesia setiap tahun menurun dan dibawah standar Internasional.

Rendahnya hasil TIMSS dan PISA di perkuat dengan realita yang ada disekolah. Setelah mewawancarai pendidik mata pelajaran matematika terkait dengan kemampuan pemecahan masalah matematika, sampai saat ini siswa masih mengalami kesulitan dalam melaksanakan langkah-langkah pemecahan masalah seperti memahami masalah, merencanakan masalah, menyelesaikan masalah, dan memeriksa kembali.

Berdasarkan studi pendahuluan (Setiyanik et al., 2020) kemampuan pemecahan masalah matematika di pengaruhi oleh berbagai macam faktor, di antaranya seperti gaya belajar siswa yang bervariasi. Oleh sebab itu pemecahan masalah matematika pada gaya belajar siswa harus dipahami oleh pendidik dalam kegiatan belajar mengajar matematika agar pendidik dapat mengetahui gaya belajar siswa tersebut. Masing - masing orang mempunyai gaya belajar tersendiri, dipengaruhi oleh watak pribadi dan lingkungan dimana siswa berada.

Gaya belajar adalah sebuah metode pendekatan yang dipilih dan digunakan oleh seseorang sesuai dengan kebutuhan dalam pembelajaran dengan menyesuaikan strategi belajar yang dibutuhkan, model pembelajaran dan gaya belajar yang dianggap sesuai dengan kemampuan seseorang akan dapat meningkatkan kemampuan belajar secara produktif (Damanik, 2015).

Menurut James and Gardner (1955) yang dikutip oleh Ghufron and Risnawita (2014) diterangkan bahwa gaya belajar adalah cara yang bervariasi bagi siswa menganggap paling baik untuk menyimpan dan merivew kembali apa yang telah dipelajari sebelumnya. DePoter dan Hernacki (2010) yang dikutip oleh Amir (2015) berpendapat bahwa gaya belajar siswa meliputi gaya belajar visual, gaya belajar auditoriak, dan gaya belajar kinestetik (V-A-K). Ciri-ciri dari gaya belajar tersebut yaitu siswa visual belajar berdasarkan penglihatannya (apa yang dilihatnya), siswa auditorial belajar berdasarkan pendengarannya (apa yang didengarnya), dan siswa kinestetik belajar berdasarkan gerakan yang disentuhnya. Betapapun setiap siswa memiliki gaya belajar visual, auditorial, dan kinestetik, akan tetapi secara individu siswa mempunyai kecenderungan salah satu dari gaya belajar. 


\section{METODE}

Dalam Penelitian ini peneliti menggunakan metode pendekatan kualitatif bersifat deskriptif. Adapun subjek penelitian yang dipakai pada penelitian ini adalah siswa kelas VII A MTS Muhammadiyah Daarul Arqam Depok berjumlah 30 siswa. Karena dimasa pandemi peneliti memberikan angket gaya belajar kepada siswa secara online yang dimana nantinya akan dipilih 3 siswa sebagai perwakilan tipe gaya belajar seperti visual, auditorial, dan kinestetik. Setelah itu 3 siswa tersebut diberikan tes kemampuan pemecahan masalah secara online. Untuk mengetahui kemampuan pemecahan masalah siswa yang ditinjau dari gaya belajar, peneliti mengumpulkan data penelitian yaitu angket gaya belajar, tes kemampuan pemecahan masalah matematis, dan pedoman wawancara.

Analisis data penelitian ini menggunakan model Miles dan Hubernan (Sugiyono 2015) seperti reduksi data, penyajian data, dan menarik kesimpulan. Mengutamakan data hasil angket gaya belajar siswa sesuai dengan gaya belajarnya merupakan reduksi data penelitian ini. Penyajian datanya hasil tes kemampuan pemecahan masalah dan proses wawancara terkait kemampuan pemecahan masalah. Menarik kesimpulan dengan analisis data yang telah dilakukan dengan hasil analisis terkait gaya belajar dan hasil wawancara terkait kemampuan pemecahan masalah matematis dan yang nantinya menyimpulkan atau mendeskripsikan kemampuan pemecahan masalah matematis ditinjau dari gaya belajar siswa. Untuk menghitung angket gaya belajar, maka peneliti menggunakan angket skala likert dengan 5 pilihan. Perhatikan pada tabel dibawah ini:

Tabel 1. Kriteria Nilai Skala Likert Angket Gaya Belajar

\begin{tabular}{|c|c|}
\hline Pilihan Jawaban & Nilai \\
\hline Sangat setuju (SS) & 5 \\
\hline Setuju (S) & 4 \\
\hline Ragu-Ragu (RG) & 3 \\
\hline Tidak Setuju (TS) & 2 \\
\hline Sangat Tidak Setuju (STS) & 1 \\
\hline
\end{tabular}

(Arikunto, 2018)

Pasca menganalisis data dengan memberikan skor diatas, lalu peneliti menghitung presentasenya. Kemudian pada kemampuan pemecahan masalah matematis terdapat 4 indikator yang digunakan, berikut tabelnya:

Tabel 2. Pedoman Penilaian Kemampuan Pemecahan Masalah Matematis

\begin{tabular}{|l|l|l|l|}
\hline \multicolumn{1}{|c|}{ Kriteria } & \multicolumn{1}{|c|}{0} & \multicolumn{1}{c|}{ 2 } & \multicolumn{1}{c|}{ Kurang memahami } \\
\hline $\begin{array}{l}\text { Memahami } \\
\text { masalah }\end{array}$ & $\begin{array}{l}\text { Tidak memahami } \\
\text { masalah }\end{array}$ & $\begin{array}{l}\text { Mampu memahami } \\
\text { masalah }\end{array}$ \\
\hline $\begin{array}{l}\text { Merencanakan } \\
\text { masalah }\end{array}$ & $\begin{array}{l}\text { Tidak mampu } \\
\text { merencanakan } \\
\text { masalah }\end{array}$ & $\begin{array}{l}\text { Mampu merencanakan } \\
\text { masalah, teatapi tidak } \\
\text { tepat }\end{array}$ & $\begin{array}{l}\text { Mampu merencanakan } \\
\text { masalah }\end{array}$ \\
\hline $\begin{array}{l}\text { Menyelesaikan } \\
\text { masalah }\end{array}$ & $\begin{array}{l}\text { Tidak mampu } \\
\text { menyelesaikan } \\
\text { masalah }\end{array}$ & $\begin{array}{l}\text { Mampu } \\
\text { menyelesaikan } \\
\text { masalah, tetapi tidak } \\
\text { tepat }\end{array}$ & $\begin{array}{l}\text { Mampu merencanakan } \\
\text { masalah dengan tepat }\end{array}$ \\
\hline
\end{tabular}




\begin{tabular}{|l|l|l|l|}
\hline $\begin{array}{l}\text { Memeriksa } \\
\text { kembali }\end{array}$ & $\begin{array}{l}\text { Tidak mampu } \\
\text { membuat } \\
\text { kesimpulan }\end{array}$ & $\begin{array}{l}\text { Mampu membuat } \\
\text { kesimpulan, tetapi } \\
\text { tidak tepat }\end{array}$ & $\begin{array}{l}\text { Mampu membuat } \\
\text { kesimpulan }\end{array}$ \\
\hline
\end{tabular}

(Sumaryanta, 2015)

Gaya belajar mempunyai 3 tipe yang meliputi visual, auditorial, dan kinestetik. Masing-masing tipe gaya belajar mempunyai indikator, diantaranya:

Tabel 3. Indikator Gaya Belajar Visual, Auditorial, dan Kinestetik

\begin{tabular}{|c|c|c|}
\hline Visual & Auditorial & Kinestetik \\
\hline $\begin{array}{l}\text { 1. } \\
\text { 2. } \text { Beri dan teratur. } \\
\text { 3. Perencana dengan cepat. } \\
\text { jangka panjang yang } \\
\text { baik. } \\
\text { 4. Teliti terhadap detail. } \\
\text { 5. } \\
\text { Mementingkan } \\
\text { penampilan, baik dalam } \\
\text { hal pakaian maupun } \\
\text { presentasi. } \\
\text { 6. Pengeja yang baik dan } \\
\text { dapat melihat kata-kata } \\
\text { yang sebenarnya dalam } \\
\text { pikiran mereka. } \\
\text { 7. Mengingat apa yang } \\
\text { dilihat, daripada yang } \\
\text { didengar. } \\
\text { 8. Mengingat dengan } \\
\text { asosiasi visual. } \\
\text { 9. Biasanya tidak terganggu } \\
\text { oleh keributan. } \\
\text { 10. Mempunyai masalah } \\
\text { untuk mengingat } \\
\text { instruksi verbal kecuali } \\
\text { jika ditulis dan seringkali } \\
\text { minta bantuan orang } \\
\text { untuk mengulanginya. } \\
\text { 11. Pembaca cepat dan } \\
\text { tekun. } \\
\text { 12. Lebih suka membaca } \\
\text { daripada dibacakan. } \\
\text { 13. Membutuhkan } \\
\text { pandangan dan tujuan } \\
\text { yang menyeluruh dan } \\
\text { bersikap waspada } \\
\text { sebelum secara mental } \\
\text { merasa pasti tentang } \\
\text { suatu masalah atau } \\
\text { proyek. } \\
\text { 14. Mencorat-coret tanpa arti } \\
\text { selama berbicara di } \\
\text { telepon dan dalam rapat. } \\
\text { 15. Lupa menyampaikan } \\
\text { pesan verbal kepada } \\
\text { orang lain. }\end{array}$ & $\begin{array}{l}\text { 1. } \begin{array}{l}\text { Berbicara pada diri } \\
\text { sendiri saat bekerja. } \\
\text { 2. Mudah terganggu oleh } \\
\text { keributan. }\end{array} \\
\text { 3. Menggerakkan bibir dan } \\
\text { mengucapkan tulisan di } \\
\text { buku ketika membaca. } \\
\text { 4. Senang membaca keras } \\
\text { dan mendengarkan. } \\
\text { 5. Dapat mengulangi } \\
\text { kembali dan menirukan } \\
\text { nada, birama, dan warna } \\
\text { suara. } \\
\text { Merasa kesulitan untuk } \\
\text { menulis, tetapi lebih } \\
\text { hebat bercerita. } \\
\text { Berbicara dalam irama } \\
\text { yang terpola. } \\
\text { 8. } \begin{array}{l}\text { Biasanya pembicara yang } \\
\text { fasih. }\end{array} \\
\text { 9. Lebih suka musik } \\
\text { daripada seni. } \\
\text { 10. Belajar dengan } \\
\text { mendengarkan dan } \\
\text { mengingat apa yang } \\
\text { didiskusikan daripada } \\
\text { yang dilihat. } \\
\text { 11. Suka berbicara, } \\
\text { berdiskusi dan } \\
\text { menjelaskan sesuatu } \\
\text { dengan panjang lebar. } \\
\text { 12. Mempunyai masalah } \\
\text { dengan pekerjaan- } \\
\text { pekerjaan yang } \\
\text { melibatkan visualisasi, } \\
\text { seperti memotong } \\
\text { bagian-bagian hingga } \\
\text { sesuai satu sama lain. } \\
\text { 13. Lebih pandai mengeja } \\
\text { dengan keras daripada } \\
\text { menuliskannya. } \\
\text { 14. Lebih suka gurauan lisan } \\
\text { daripada membaca } \\
\text { komik. }\end{array}$ & $\begin{array}{l}\text { 1. Berbicara dengan } \\
\text { perlahan. } \\
\text { 2. Menanggapi perhatian } \\
\text { fisik. } \\
\text { 3. Menyentuh orang untuk } \\
\text { mendapatkan perhatian } \\
\text { mereka. } \\
\text { 4. Berdiri dekat ketika } \\
\text { berbicara dengan orang. } \\
\text { 5. Selalu berorientasi pada } \\
\text { fisik dan banyak bergerak } \\
\text { 6. Mempunyai } \\
\text { perkembangan otot-otot } \\
\text { yang besar. } \\
\text { 7. Belajar melalui } \\
\text { memanipulasi dan praktik. } \\
\text { 8. Menghafal dengan cara } \\
\text { berjalan dan melihat. } \\
\text { 9. Menggunakan jari sebagai } \\
\text { penunjuk ketika membaca. } \\
\text { 10. Banyak menggunakan } \\
\text { isyarat tubuh. } \\
\text { 11. Tidak dapat duduk diam } \\
\text { untuk waktu lama. } \\
\text { 12. Tidak dapat mengingat } \\
\text { geografi, kecuali jika } \\
\text { mereka telah pernah } \\
\text { berada di tempat itu. } \\
\text { 13. Menggunakan kata yang } \\
\text { mengandung aksi. } \\
\text { 14. Menyukai buku-buku yang } \\
\text { berorientasi pada plot- } \\
\text { mereka mencerminkan } \\
\text { aksi dengan gerakan tubuh } \\
\text { saat membaca. } \\
\text { 15. Kemungkinan tulisannya } \\
\text { jelek. } \\
\text { 16. Ingin melakukan segala } \\
\text { sesuatu. } \\
\text { 17. Menyukai permainan yang } \\
\text { menyibukkan. }\end{array}$ \\
\hline
\end{tabular}


16. Sering menjawab pertanyaan dengan jawaban singkat ya atau tidak.

17. Lebih suka melakukan demonstrasi daripada berpidato.

18. Lebih suka seni daripada musik.

19. Seringkali mengetahui apa yang harus dikatakan, tetapi tidak pandai memilih katakata.

20. Kadang-kadang kehilangan konsentrasi ketika mereka ingin memperhatikan.

Penelitian ini lebih menggunakan wawancara semiterstruktur Wawancara disini bertujuan untuk mengetahui lebih mendalam terhadap masalah yang dihadapi subjek terkait dengan kemampuan pemecahan masalah.

\section{HASIL DAN DISKUSI}

Peneliti telah menyebarkan angket gaya belajar kepada 30 siswa. Dari hasil angket yang telah dibagikan kepada siswa, peneliti mendapatkan informasi terkait gaya belajar siswa dimasa pandemi COVID-19. Data hasil gaya belajar yang diperoleh dan dihitung tiap-tiap skornya dari masing-masing indikator, maka menghasilkan data sebagai berikut:

Tabel 4. Data Hasil Angket Gaya Belajar

\begin{tabular}{|c|c|}
\hline Gaya Belajar yang digunakan & Jumlah Data Siswa \\
\hline Visual (V) & 12 \\
\hline Auditorial (A) & 6 \\
\hline Kinestetik (K) & 12 \\
\hline
\end{tabular}

Sesuai dengan tabel diatas yaitu hasil gaya belajar siswa didapati bahwa siswa yang mengerjakan angket adalah 30 siswa dengan rincian 12 siswa mempunyai tipe gaya belajar visual, 6 siswa mempunyai tipe gaya belajar auditorial, dan 12 siswa mempunyai tipe gaya belajar kinestetik. Setelah memberikan tes, peneliti menganalisis tes tersebut sesuai dengan angket yang telah diisi. Selanjutnya peneliti memilih 3 siswa dari tiap tipe gaya belajar terhadap kemampuan pemecahan masalah matematis menurut polya yang diantaranya memahami masalah, merencanakan masalah, menyelesaikan masalah, memeriksa kembali.

\section{Gaya Belajar Visual}

Pada tahap memahami masalah, KK mampu memahami masalah dengan cara menyebutkan hal yang diketahui dan menyebutkan hal yang ditanyakan dalam soal secara cepat dan benar, tetapi dalam wawancara 
KK merasa ada yang kebingungan menyebutkan hal yang diketahui jika ada angka dalam soal yang mengecohkannya.

Pada tahap merencanakan masalah, KK mampu menyebutkan rumus yang digunakan dalam merencanakan masalah. KK merasa kesulitan menentukan rumus dengan salah satu soal, tetapi ketika diadakannya wawancara KK mampu menyebutkan rumus dengan tepat dan benar. KK mampu mengoperasikan dengan lengkap rumus tersebut untuk menyelesaikan masalah menggunakan langkah langkah yang sesuai dengan soal karena KK sudah pernah menjumpai soal-soal seperti ini.

KK mampu untuk memeriksa kembali dengan cara memeriksa kembali jawaban hasil pemecahan masalah yang telah dikerjakan dari awal sampai akhir soal, tetapi KK tidak menyimpulkan jawaban dari penyelesaian masalah untuk setiap soalnya dikarenakan ketika diadakannya wawancara KK lebih fokus menyelesaikan masalah. Sehingga KK lupa tidak menyimpulkan kesimpulan tetapi KK paham bahwa setiap soal harus dicantumkan kesimpulan diakhir soal.

\section{Gaya Belajar Auditorial}

AM mampu memahami masalah dengan cara menyebutkan hal yang diketahui dan menyebutkan hal yang ditanyakan dalam soal walaupun dalam wawancara ada beberapa soal yang membuat AM bingung menentukan diketahui dan ditanyakan. Pada tahap ini, AM kurang mampu menyebutkan rumus yang digunakan dalam merencanakan masalah karena ketika diadakannya wawancara AM tidak pernah menemukan soal-soal semacam ini, AM merasa kesulitan menentukan rumus dalam beberapa soal yang ada

AM kurang mampu menyelesaikan masalah dengan mengoperasikan rumus untuk menyelesaikan menggunakan langkah - langkah yang sesuai dengan soal, tetapi dalam beberapa soal, AM mampu menyelesaikan masalah walaupun tidak semua soal dikerjakan. Meskipun terdapat kesalahan perhitungan dalam mengoperasikan rumus. Kesalahan tersebut akibat siswa kurang teliti dalam perhitungan Pada tahap ini, AM kurang mampu dalam memeriksa kembali jawaban hasil pemecahan masalah yang telah dikerjakan, tetapi AM mampu menyimpulkan satu jawaban dari penyelesaian masalah. Ketika diadakannya wawancara, AM lupa tidak menyimpulkan semua soal yang dikerjakannya.

\section{Gaya Belajar Kinestetik}

Pada tahap memahami masalah, FM mampu memahami masalah dengan baik dengan cara menyebutkan hal yang diketahui dan menyebutkna hal yang ditanyakan. ketika diadakannya wawancara, FM masih kebingungan dengan hal yang diketahui. Pada tahap merencanakan masalah, FM kurang mampu merencanakan masalah, ketika diadakannya wawancara FM pernah menjumpai soal seperti ini tetapi hanya sedikit. Dibeberapa soal FM tidak menyebutkan rumus karena FM kesulitan merencanakan masalah yaitu rumus. Pada tahap menyelesaikan masalah, FM mampu dalam melakukan perhitungan dengan mengoperasikan rumus untuk menyelesaikan langkah - langkah. Dalam beberapa soal FM kurang mampu menyelesaikan masalah dikarenakan kurangnya konsentrasi

FM mampu memeriksa kembali jawaban hasil pemecahan masalah tetapi FM tidak menyimpulkan jawaban setiap soal. 
Tabel 5. Hasil Penelitian Kemampuan Pemecahan Masalah Matematis Ditinjau dari Gaya Belajar Siswa Dimasa Pandemi COVID-19

\begin{tabular}{|l|l|l|l|}
\hline $\begin{array}{c}\text { Kemampuan } \\
\text { pemecahan } \\
\text { masalah } \\
\text { Menurut Polya) }\end{array}$ & \multicolumn{1}{|c|}{ Visual (KK) } & \multicolumn{1}{|c|}{ Auditorial (AM) } & \multicolumn{1}{c|}{ Kinestetik (FM) } \\
\hline $\begin{array}{l}\text { Memahami } \\
\text { masalah }\end{array}$ & $\begin{array}{l}\text { Mampu mengungkapkan } \\
\text { dan menuliskan hal yang } \\
\text { diketahui dan hal yang } \\
\text { ditanyakan }\end{array}$ & $\begin{array}{l}\text { Mampu mengungkapkan } \\
\text { dan menuliskan hal yang } \\
\text { diketahui dan hal yang } \\
\text { ditanyakan }\end{array}$ & $\begin{array}{l}\text { Mampu mengungkapkan } \\
\text { dan menuliskan yang } \\
\text { diketahui dan hal yang } \\
\text { ditanyakan }\end{array}$ \\
\hline $\begin{array}{l}\text { Merencanakan } \\
\text { masalah }\end{array}$ & $\begin{array}{l}\text { Mampu menuliskan } \\
\text { semua rumus yang } \\
\text { digunakan dalam } \\
\text { merencanakan masalah }\end{array}$ & $\begin{array}{l}\text { Kurang mampu } \\
\text { menuliskan semua } \\
\text { rumus yang digunakan } \\
\text { dalam merencanakan } \\
\text { masalah }\end{array}$ & $\begin{array}{l}\text { Kurang mampu } \\
\text { menuliskan semua } \\
\text { rumus yang digunakan } \\
\text { dalam merencanakan } \\
\text { masalah }\end{array}$ \\
\hline $\begin{array}{l}\text { Menyelesaikan } \\
\text { masalah }\end{array}$ & $\begin{array}{l}\text { Mampu dalam melakukan } \\
\text { perhitungan dengan } \\
\text { mengoperasikan rumus } \\
\text { untuk menyelesaikan } \\
\text { langkah - langkah }\end{array}$ & $\begin{array}{l}\text { kurang mampu } \\
\text { menyelesaikan masalah } \\
\text { dengan mengoperasikan } \\
\text { rumus untuk } \\
\text { menyelesaikan langkah } \\
\text { - langkah }\end{array}$ & $\begin{array}{l}\text { Mampu dalam } \\
\text { melakukan perhitungan } \\
\text { dengan mengoperasikan } \\
\text { rumus untuk } \\
\text { menyelesaikan langkah } \\
\text { - langkah }\end{array}$ \\
\hline $\begin{array}{l}\text { Memeriksa } \\
\text { kembali }\end{array}$ & $\begin{array}{l}\text { Mampu memeriksa } \\
\text { kembali hasil pemecahan } \\
\text { masalah } \\
\text { Tidak membuat } \\
\text { kesimpulan }\end{array}$ & $\begin{array}{l}\text { Kurang memeriksa } \\
\text { kembali hasil } \\
\text { pemecahan masalah } \\
\text { Tidak membuat } \\
\text { kesimpulan }\end{array}$ & $\begin{array}{l}\text { Mampu memeriksa } \\
\text { kembali hasil } \\
\text { pemecahan masalah } \\
\text { Tidak membuat } \\
\text { kesimpulan }\end{array}$ \\
\hline
\end{tabular}

(Umrana et al., 2019)

Data diatas menunjukkan bahwa kemampuan pemecahan masalah dari gaya belajar visual, auditorial, dan kinestik memiliki kemampuan yang berbeda. Salah satu faktornya adalah gaya belajar. Dapat dilihat kemampuan pemecahan masalah diatas dari masing-masing gaya belajar masih kurang dikarenakan kemampuan dasar matematika siswa khususnya cara menghitung baik perkalian atau pembagian ataupun tidak bisa memecahkan masalah atau tidak menghafal rumus yang nantinya berdampak pada penyelesaian masalahnya. Tetapi dalam penelitian ini yang lebih berpengaruh adalah gaya belajar visual, dikarenakan siswa lebih memahami kemampuan pemecahan masalah matematis dalam menyelesaikan masalah.

Kelemahan penelitian ini dapat dijadikan contoh bahwa tidak semua gaya belajar dapat menerima pembelajaran matematika karena setiap gaya belajar mempunyai kekurangan dan kelebihan bagi siswa itu sendiri. Penelitian ini juga menghasilkan sebuah gambaran bahwa hasil penelitian hanya berlaku pada subjek yang diteliti namun dapat dijadikan contoh selanjutnya, sebaiknya jika ingin meneliti lebih lanjut, harus dilakukan pengkajian terhadap gaya belajar dalam menyelesaikan masalah matematis dengan saksama.

\section{KESIMPULAN}

Sesuai dengan hasil penelitian dan analisis data bahwa hasil penelitian di MTS Muhammadiyah Daarul Arqam Depok dimasa pandemi COVID-19 pada siswa kelas VII A bahwa kemampuan pemecahan masalah matematis yang mempunyai gaya belajar visual mampu memahami masalah dengan cara 
Analisis Kemampuan Pemecahan Masalah Matematis di Tinjau dari Gaya Belajar Siswa di Masa Pandemi COVID-19, Intan

menuliskan hal yang diketahui dan hal yang ditanyakan, mampu merencanakan masalah dengan mengetahui rumusnya terlebih dahulu, mampu menyelesaikan langkah - langkah, dan mampu memeriksa kembali hasil pemecahan masalah. Kemampuan pemecahan masalah matematis yang mempunyai gaya belajar auditorial, mampu memahami masalah dengan cara menuliskan hal yang diketahui dan hal yang ditanyakan, kurang mampu merencanakan masalah dengan mengetahui rumusnya terlebih dahulu, kurang mampu menyelesaikan langkah - langkah, dan kurang mampu memeriksa kembali hasil pemecahan masalah. Kemampuan pemecahan masalah matematis dengan tipe gaya belajar kinestetik, mampu memahami masalah dengan cara menuliskan hal yang diketahui dan hal yang ditanyakan, kurang mampu merencanakan masalah dengan mengetahui rumusnya terlebih dahulu, mampu menyelesaikan langkah - langkah, dan kurang mampu memeriksa kembali hasil pemecahan masalah yang ada.

Siswa yang mempunyai gaya belajar visual setara dengan penelitian terdahulu, dan yang membandingkannya dengan hasil penelitian terdahulu (Umrana et al., 2019) adalah siswa yang mempunyai gaya belajar auditorial mampu memahami masalah dengan cara menuliskan hal yang diketahui dan hal yang ditanyakan. Siswa yang mempunyai gaya belajar kinestetik kurang mampu merencanakan masalah dengan mengetahui rumusnya terlebih dahulu dan kurang mampu memeriksa kembali hasil pemecahan masalah yang ada.

\section{REFERENSI}

Amir, Mohammad Faizal. 2015. "Proses Berpikir Kritis Siswa Sekolah Dasar Dalam Memecahkan MasalahBerbentuk Soal Cerita Matematika Berdasarkan Gaya Belajar.” Jurnal Math Educator Nusantara 1 (2): 159-70. https://ojs.unpkediri.ac.id/index.php/matematika/article/view/235.

Arikunto, Suharsimi. 2018. Dasar-Dasar Evaluasi Pendidikan. Edited by Restu Damayanti. 3rd ed. Jakarta: Bumi Aksara.

Damanik, Jafriansen. 2015. “Gaya Belajar Mahasiswa Yang Bekerja : Penelitian Di STKIP Purnama Jakarta.” JDP 8 (1): 25-34. https://doi.org/https://doi.org/10.51212/jdp.v8i1.111.

Dassa, Awi. 2018. Pemecahan Masalah Matematika. 1st ed. Makassar: Global-RCI.

Ghufron, M. Nur, and Rini Risnawita. 2014. Gaya Belajar : Kajian Teoritik. 2nd ed. Yogyakarta: Pustaka Belajar.

Mullis, Ina V S, Michael O Martin, Pierre Foy, and Martin Hooper. 2015. “TIMSS 2015 International Results in Mathematics."

OECD. 2017. PISA 2015 Assessment and Analytical Framework: Science, Reading, Mathematic, Financial Literacy and Collaborative Problem Solvin. Edited by PISA. Revised ed. Paris: OECD. https://doi.org/http://dx.doi.org/10.1787/9789264281820-en.

Setiyanik, Liyan, Junarti Junarti, and Anita Dewi Utami. 2020. "Profil Pemecahan Masalah Siswa Dalam Menyelesaikan Masalah Aritmatika Sosial Ditinjau Dari Gaya Belajar.” JPM : Jurnal Pendidikan Matematika 6 (1): 6-14. https://doi.org/10.33474/jpm.v6i1.2983.

Sugiyono. 2015. Metode Penelitian Pendidikan : Pendekatan Kuantitatif, Kualitatif, Dan R\&D. 22nd ed. 


\section{Bandung: CV Alfabeta.}

Sumaryanta. 2015. "Pedoman Penskoran." Indonesian Digital Journal of Mathematics and Education. 2

(3): 181-90.

Supriani, Yani, Giyani, and Tb Sofwan Hadi. 2020. "Conjecturing Ability Dalam Pembelajaran Daring Masa Pandemi Covid-19." Inomatika 2 (2): 161-69.

https://doi.org/https://doi.org/10.35438/inomatika.v2i2.201.

Umrana, Edi Cahyono, and Muhammad Sudia. 2019. “Analisis Kemampuan Pemecahan Masalah Matematis Ditinjau Dari Gaya Belajar Siswa.” Jurnal Pembelajaran Berpikir Matematika 4 (1): 67 76. 